\title{
腹腔鏡下胵式子宮全摘術における手術時間の手術侵襲への影響 Effect of operating time on surgical injury in laparoscopically assisted vaginal hysterectomy
}

石川県立中央病院産婦人科

干場 勉、佐々木博正、平吹信弥、朝本明弘、矢吹朗彦

\section{緒言}

腹腔鏡下腟式子宮全摘術が多く行われるように なると、強い癒着例や巨大筋腫例も対象となって くるが、そのような手術では不良視野や瘉着剥離 での丁寧な操作などに時間を要してしまう。

開腹手術では一般に長時間手術は大手術である。 しかし、腹腔鏡下手術や腟式手術は元来低侵襲手 術であり、それらが時間により臨床的にどの程度 影響を受けているかを検討することは、今後高度 の腹腔鏡下手術を行っていく点で重要と思われる。

そこで、ほぼ同一手技である腹腔鏡下胵式子宮 全摘術（以下LAVH）における手術時間による侵 襲を検討した。

\section{対象と方法}

同一術式で単にゆっくり時間をかけるだけの手 術は倫理的に行えない。そこで手術時間による影 響を見るため、他の条件を極力一定にする試みと してLAVHという基本的に同一操作（子宮周囲組 織の剥離、切離と縫合、付属器は場合により摘出） を同一術者により行う手術での短時間群と長時間 群で術中術後の状態を比較した。

対象を手術所要時間で分けてA群：1〜2時 間、B群： $3 \sim 6$ 時間の 2 群とし、術中は手術時 間と出血量や子宮重量、術後状態の検討としては 術後歩行開始時間、解熱鎮痛剂使用（主に鎮痛目 的）の有無、38度以上の発熱の有無、手術 2 日後 の白血球数、CRP、合併症、術後入院日数を比較 したが、保険などの関係で長期入院を希望した症 例は除外した。

当院のLAVH術式は $5 \mathrm{~mm}$ トロッカーを 3 本 （場合により 4 本）使用し、付属器切離（切除）
はバイポーラで凝固後行い、膀胱子宮窩腹膜切開 後に胵式操作を施行した。また、硬膜外麻酔は術 中のみに塩酸モルヒネを投与し、手術終了時に硬 膜外チューブは抜去していた。

統計学的検定はStudentのtテストと $\chi^{2}$ 検定を 用いた。

\section{結＼cjkstart果}

症例はA群 42 例、B群 16 例であった。年齢の平 均土標準偏差（最小-最大） (以下同じ) はA群

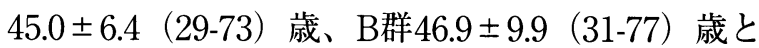
差はなかった（表 1 )。疾患は両群ともに子宮筋 腫と子宮内膜症であり、70歳以上の高齢者はA群 は子宮内膜増殖症 1 例、 $\mathrm{B}$ 群は子宮付属器膿瘍 1 例 であった。

表 1 腹腔鏡下胵式子宮全摘術例の臨床所見

\begin{tabular}{|c|c|c|}
\hline & A : 1 2 時間 & B : 3-6時間 \\
\hline 症例数 & 42 & 16 \\
\hline 年龄(歲) & $45.0 \pm 6.4(29-73)$ & $46.9 \pm 9.9(31-77)$ \\
\hline 手術時間(分)* & $96.2 \pm 13.8(60-118)$ & $215.4 \pm 31.0(180-294)$ \\
\hline 子宮重量(g)* & $195.1 \pm 69.8(75-380)$ & $345.3 \pm 234.5(83-910)$ \\
\hline 出血量(ml)* & $93.3 \pm 55.8(10-250)$ & $273.4 \pm 161.6(55-640)$ \\
\hline 術後歩行開始 & $22.8 \pm 4.2(16-36)$ & $25.5 \pm 7.6(16-40)$ \\
\hline 鎮痛荗使用 & $79 \%(32 / 42)$ & $81 \%(13 / 16)$ \\
\hline 発熱(>38 $\left.{ }^{\circ} \mathrm{C}\right)$ & $24 \%(10 / 42)$ & $44 \%(7 / 16)$ \\
\hline 白血球数 & $6030 \pm 1500(3100-9800)$ & $6163 \pm 2128(3600-13200)$ \\
\hline C R P & $2.5 \pm 3.7(0.1-6.1)$ & $2.9 \pm 2.6(0.6-10.2)$ \\
\hline 術後入院日数 & $6.3 \pm 1.3(4-9)$ & $6.4 \pm 1.5(4-9)$ \\
\hline
\end{tabular}

手術時間はA群96.2 土13.8（60-118） 分、B群 $215.4 \pm 31.0$ （180-294）分であり、B群の手術時間 の延長は癒着の存在や、腟の狭小、摘出物の大き さに起因していた。子宮重量はA群 $195.1 \pm 69.8$ (75-380） g、B群345.3 \pm 234.5 （83-910） gとB群の 方が重かった。

出血量はA群93.3 $\pm 55.8 （ 10-250 ） \mathrm{ml}$ 、B群 
$273.4 \pm 161.6$ （55-640） $\mathrm{ml}$ とB群で多かったが、こ れは癒着剥離や摘出物の細切の際に失われたもの であった。

術後歩行開始はA群22.8 $44.2 （ 16-36 ）$ 時間に対 しB群は25.5 23.9 （16-40）時間と長い傾向があっ たが、有意差はなかった。解熱鎮痛剤使用はA群 $79 \%(9 / 42) 、 B$ 群 $81 \%(3 / 16)$ と差は無く、38 度以上の発熱はA群 $24 \%(10 / 42) 、 B$ 群 $44 \%$ （7/16）だったが有意差はなかった。

術後白血球数はA群6030 1500 （3100-9800）、

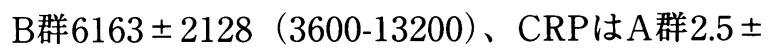
3.7 (0.1-6.1)、B群2.9 2.6 (0.6-10.2) と各群で有 意差はなかった。術後入院日数もA群6.3 \pm 1.3 （49）日、B群6.4 $\pm 1.5 （ 4-9)$ 日と差はなく、手術時 間が長いために入院期間が延長している所見は見 られなかった（図1)。

また、合併症では 1 例が電気メスによる腸管熱 損傷による縫合を行ったが、術後 7 日後に退院と なっていた。

図 1 腹腔鏡下腟式子宮全摘術の手術時間と術後入院日数

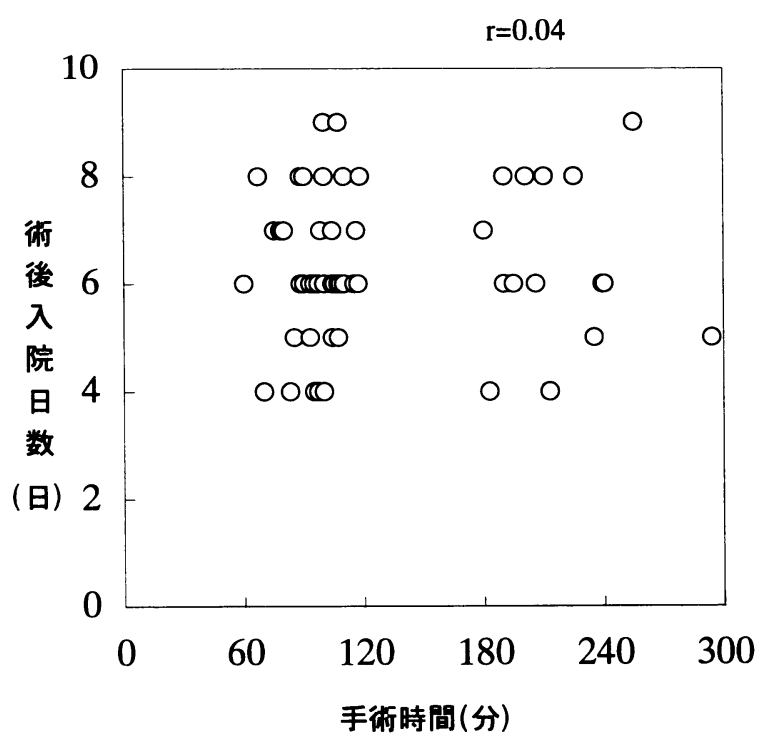

\section{考 察}

手術が長時間となる原因には困難な操作（癒着 剥離、縫合、大腫瘤による視野不良や回収）の他 に、術者の未熟（技術、迷い、不要な操作とそれ に伴う修復）もあるが、手術操作が愛護的で臓器 損傷や出血を回避する姿勢も考えられる。腹腔鏡 下では鉗子は細く、操作や視野の方向が限定され ているため開腹手術よりも時間延長傾向は顕著と なりやすい。

手術時間延長の悪影響は一般的には出血や感 染、臓器損傷など合併症の機会が増えることであ
る。また、創の乾燥や損傷に伴う創の治癒の遅延、 さらに腸閉塞の合併などは開腹手術ではよく経験 するところである。しかし、腹腔鏡下手術と開腹 手術を比較すると、手術時間は延長するが、術後 の回復までの期間が短縮することはよく報告され ている ${ }^{1-4)}$ 。

今回手術時間の延長により有意差が認められた のはB群での平均 $180 \mathrm{ml}$ の術中出血量増加のみで あった。これは開腹手術でも経験するような剥離 面からの出血が持続する時間が長くなることが一 因と考えられたが、気腹圧である程度少なくなっ ているのかもしれない。また、B群では子宮重量 が大きく子宮への循環血液量も多いが、腟式にこ れを回収するには細切が必要となる。理論的には 当院のLAVHでは子宮動脈切断は最後となるた め、子宮細切時は子宮内に貯留した血液が術野に 出る。そのため開腹では標本重量となる血液が術 中出血量として算定されて術中出血量が多くなる 可能性もあろう。

B群で有意差はないものの発熱が多く、また CRPがやや高値の傾向を示したのは、瘉着剥離面 積の大小が影響していると思われた。また、術後 の歩行開始遅延傾向は長時間手術だから遅らせた ほうがよいとの看護面での意向が反映されたため と考えられた。

臨床的に早期の侵襲が示されるのは鎮痛剤使用 や発熱、白血球、CRPであるが、LAVHのA群 $\mathrm{B}$ 群で有意差はなかった。解熱鎮痛剛使用で差がな かったことからも、患者自身の術後侵襲の自覚と いう点では同等のようである。また、開腹手術で 3 時間半以上となると腸機能の回復などに時間を 要することを経験するが、そのような合併症は見 られなかった。さらに、術後の回復状態をもっと もよく示すと考えられるのは入院日数と思われる が、これも長時間のために入院日数が長くなるこ ともなかった。

以上から、LAVHでは手術時間延長は術後回復 にはあまり影響を与えていないと考えられた。す なわち、腹腔鏡下手術ではほほ同一操作を行うな らば、長時間を要していても臨床的には低侵襲の ままであると考えられた。したがって長時間とい う体制が許されるならば、丁寧な操作や手術適応 拡大により更に低侵襲手術例を増加させることが 可能と思われた。

本論文の要旨は第 41 回日本産科婦人科内視鏡学会 （長崎）において発表した。 


\section{文献}

1) Wood C, Maher PJ: Laparoscopic hysterectomy. Baillieres's Clinic. Obstet. Gynecol. 11:111-136, 1997.

2 ) Nezhat F et al. : Laparoscopic versus abdominal hysterectomy. J.Reprod. Med.37:247-250,1992.

3 ) Ducette RC, Scott JR: Comparison of laparoscopically assisted vaginal hysterectomy with abdominal and vaginal hysterectomy. J. Reprod. Med. 41:1-6,1996

4 ）廣田 譲、他：腹腔鏡下手術症例における術後の 社会復帰に関する検討一開腹手術症例との比較検 討による腹腔鏡下手術の手術侵襲解析一：日産婦 内視鏡誌, $16: 48-50,2000$. 